\title{
Nasal Cavity and Ethmoid Sinus Cancer TNM Finding v7
}

National Cancer Institute

\section{Source}

National Cancer Institute. Nasal Cavity and Ethmoid Sinus Cancer TNM Finding v7. NCI

Thesaurus. Code C89105.

A finding about one or more characteristics of nasal cavity and ethmoid sinus cancer, following the rules of the TNM AJCC v7 classification system. 